\title{
Nankai Trough, Japan Trench and Kuril Trench: geochemistry of Fluids sampled by submersible "Nautile"
}

\author{
Jacques Boulègue ${ }^{1}$, Jean T. Iiyama ${ }^{2}$, Jean-Luc Charlou ${ }^{3}$ and Jacques Jedwab ${ }^{4}$ \\ 'Laboratoire de Géochimie et Métallogénie (CNRS UA 196). Université Pierre et Marie Curie, \\ 4 place Jussieu, 75252 Paris Cédex OS (France) \\ ? Faculty of Science, University of Tokyo, Bunkyo-ku, Tokyo 113 (Japan) \\ 3 D3GM, IFREMER, Centre de Brest, B.P. 337, 29273 Brest Cédex (France) \\ - Laboratoire de Géochimie, Université Libre de Bruxelles, 50 Al. F.D. Roosevelt, B-1050 Bruxelles (Belgique)
}

Revised version accepted February 5, 1987

\begin{abstract}
Deep-water samples collected during the Kaiko project are often associated with biological communities located on geological structures favorable to fluid venting. The evidence of fluid venting are the temperature anomalies, the decrease in sulfate concentrations, the content in methane and the low $C_{1} /\left(C_{2}+C_{3}\right)$ ratio of light hydrocarbons. Because of large dilution by ambiant seawater during sampling it is difficult to compute the composition of the advected end-member pore fluid. Part of this fluid should originate in the "petroleum window", i.e. at temperature about $60^{\circ} \mathrm{C}$. Modeling the upward flow of water, taking into account the anomalies of temperature measured on the seafloor and the geochemical anomalies. leads to non-steady-state advection of the pore fluid. The occurrence of a deep component in the fluid has implications for the geological and tectonic models of the subduction zones off Japan.
\end{abstract}

\section{Introduction}

The discovery of clam communities associated with fluid venting in the accretionary complex of the Oregon subduction zone has opened the discussion on the origin and the source depth of the advecting fluids $[1,2]$. One of the purposes of the Kaiko program was to test the possibility of advection of fluids associated with the dewatering of the accretionary prism in the subduction zones off Japan. There were some previous hints that such advection was occurring from the DSDP results off northern Japan [3]. It was found that the light hydrocarbon ratio $C_{1} / C_{2}$ was possibly lowered by inputs of petrogenetic hydrocarbons and that the $\delta^{13} \mathrm{C}$ of $\mathrm{CH}_{4}$ was correlatively lowered [3]. Hence, the bottom water sampling during the Kaiko legs was oriented towards understanding these possible processes at locations where the presence of biological communities indicate that fluids may be venting. The capability of handling tools from the submersible "Nautile" was extensively used to fulfill this program.

\section{Sampling and analyses}

The water samples were collected either with titanium syringes handled directly above the sediment interface or with an aluminium box corer and core samplers lined with plastic by withdrawing the supernatant water. The use of syringes to attempt to sample as much as possible of venting fluid associated with the biological communities posed constraints on the representativeness of the samples. The flux of fluid passing through the communities is small (see later) and so as not to damage the instrument it was deployed in the free bottom water without touching the solid substrate; hence the fluid samples were a mixture of mostly bottom water with a small percentage of fluid advecting from the sediment.

The location of the samples is listed in Table 1 and shown in Figs. 1 and 2. The samples that are clearly associated with biological communities are HY 4, 7, 8, 9, 10, 14, 15, 16. Fig. 2 shows the exact locations of the samples from the clam community in the deep-sea fan of Tenryu Canyon together with the measured temperatures. Sample HY16 


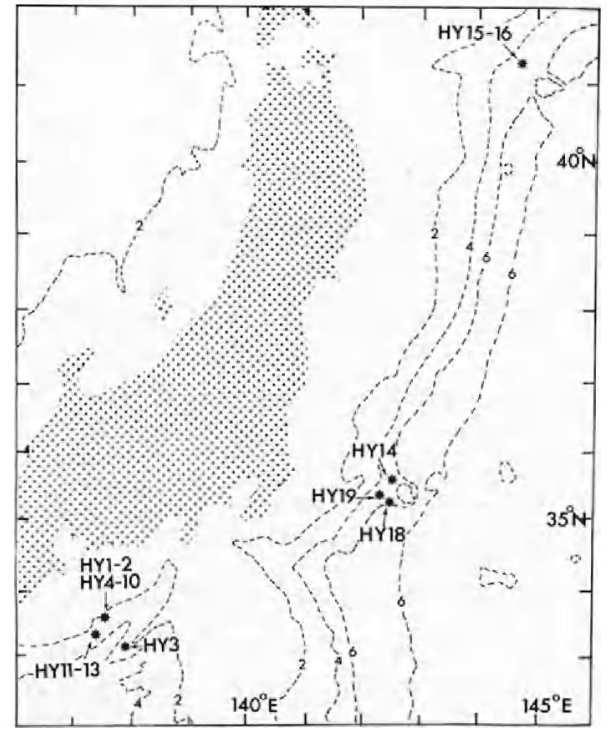

Fig. 1. General location map of deep-water samples from subduction zones of Japan.

was taken $2 \mathrm{~m}$ from sample HY15 so as to check for the effects of mixing of advecting fluids with seawater over short distances. Some of the other samples may also be associated with fluid venting

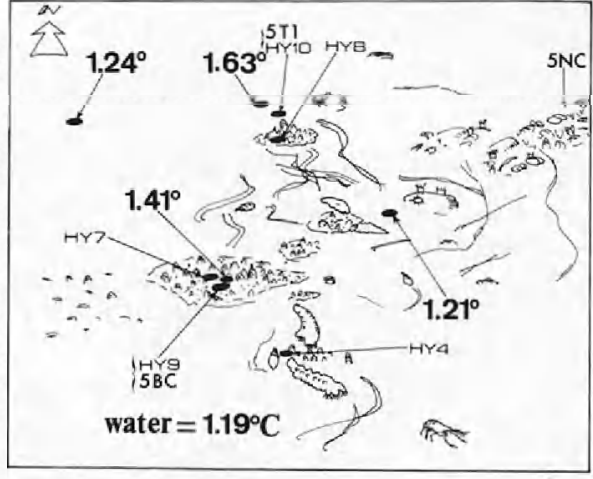

Fig. 2. Detailed sampling scheme in the biological community of Tenryu deep sea fan HY = water sample: $5 \mathrm{Tl}$. $5 \mathrm{NC}$ and 5BC are sediment samples. Measured temperatures are also given $\left({ }^{\circ} \mathrm{C}\right)$. After a drawing by $\wedge$. Taira. The black dots correspond to sampling locations and temperature measurements ( see [28]).

because of favorable geological structure. This is the case for HY3 located in a region of small ledges, in the vicinity of a thrust in the Zenisu Basin. In the vicinity of Tenryu Canyon. samples HY 1,2 and 5 will be considered as reference samples of local deep-sea water.

TABLE 1

Locations and depths of water samples obtained during Kaiko project

\begin{tabular}{|c|c|c|c|c|}
\hline Sample & Location & Depth $(m)$ & Sampler ${ }^{\text {a }}$ & Comments \\
\hline HY11 & $38^{\circ} 16^{\prime} 42 \mathrm{~N}, 137^{\circ} 24^{\prime} 1 \mathrm{SE}$ & 4187 & T.S & Nankai Trough \\
\hline HY12 & same as HY 11 & 4187 & B.C. & olive-grey semi-consolidated claystone \\
\hline HY13 & $33^{\circ} 16^{\prime} 53 \mathrm{~N}, 134^{\circ} 24^{\prime} 06 \mathrm{~F}$ & 4234 & T.C. & olive-grey semi-consolidated claystone; Nankai Trough \\
\hline HY2 & $33^{\circ} 36^{\prime} 60 \mathrm{~N}, 137^{\circ} 32^{\prime} 60 \mathrm{E}$ & 3844 & T.S. & Tenryu Canyon deep-sea fan \\
\hline HY1 & $33^{\circ} 36^{\prime} 09 \mathrm{~N}, 137^{\circ} 32^{\prime} 60 \mathrm{E}$ & 3839 & T.S. & Tenryu Canyon deep-sea fan: $\mathrm{N}$-S outcrop \\
\hline HY5 & $33^{\circ} 37^{\prime} 62 \mathrm{~N}, 137^{\circ} 32^{\prime} 10 \mathrm{E}$ & 3676 & T.S. & top of anticline: side of Tenryu Canyon \\
\hline HY4 & $33^{\circ} 36^{\prime} 35 \mathrm{~N} .137^{\circ} 32^{\prime} 25 \mathrm{E}$ & 3836 & I.S. & clam field, NW-SF fault N50 $0^{\circ}$ F flexure: Tenryu Canyon \\
\hline HY7 & same as $\mathrm{HY} 4$ & 3836 & T.S. & see Fig. 2 \\
\hline HY 8 & same as HY4 & 3836 & I.S. & sec Fig. 2 \\
\hline HY9 & same as $\mathrm{HY}_{4}$ & 3836 & B.C. & see Fig. 2 \\
\hline HY 10 & same as $\mathrm{HY} 4$ & 3836 & T.C. & see Fig. 2 \\
\hline HY6 & $33^{\circ} 36^{\prime} 21 \mathrm{~N}, 137^{\circ} 32^{\prime} 03 \mathrm{E}$ & 3830 & T.C. & olive-grey mud $300 \mathrm{~m}$ off clam field; Tenryu canyon \\
\hline HY3 & $33^{\circ} 11^{\prime} 48 \mathrm{~N}, 137^{\circ} 53^{\prime} 01 \mathrm{E}$ & 4184 & T.C. & $\begin{array}{l}\text { Zenisu Basin; coarse sandy semiconsolidated mud: } \\
\text { structure? }\end{array}$ \\
\hline HY 18 & $33^{\circ} 45^{\prime} 00 \mathrm{~N}, 142^{\circ} 29^{\prime} 56 \mathrm{E}$ & 5611 & T.S. & nank Kashima Seamount: calcareous outcrop \\
\hline HY19 & $35^{\circ} 48^{\prime} 32 \mathrm{~N}, 142^{\circ} 25^{\prime} 72 \mathrm{E}$ & 5513 & T.C. & olive-green mud; Kashima, innerwall of Japan Trench \\
\hline HY14 & $35^{\circ} 54^{\prime} 62 \mathrm{~N}, 142^{\circ} 30^{\prime} 90 \mathrm{~F}$ & 5640 & T.S. & $\begin{array}{l}\text { clam field; } N 280^{\circ} \mathrm{E} \text { flexure; innerwal of } \\
\text { Japan Trench, Kashima }\end{array}$ \\
\hline HY15 & $41^{\circ} 18^{\prime} 05 \mathrm{~N}, 144^{\circ} 44^{\prime} 07 \mathrm{E}$ & 5129 & T.S. & $\begin{array}{l}\text { clam field; small ledge on subvertical } \\
\text { fault indurated mud }\end{array}$ \\
\hline HY 16 & same as HY15 & 5129 & T.S. & $2 \mathrm{~m}$ off HYls \\
\hline
\end{tabular}

T.S. $=$ titanium syringe: B.C. $=$ box corer; T.C $=$ tube corer. 
The syringes were subsampled on board ship for ${ }^{3} \mathrm{He} /{ }^{4} \mathrm{He}$ and other rare gases measurements, for light hydrocarbons and for ${ }^{18} \mathrm{O} /{ }^{16} \mathrm{O}$ and $\mathrm{D} / \mathrm{H}$ determinations. Samples for nitrate were frozen upon recovery. The determinations of $\mathrm{pH}$ and alkalinity were done on board ship using Tris buffer as reference. Dissolved sulfide was determined by potentiometry with an $\mathrm{Ag} / \mathrm{Ag}_{2} \mathrm{~S}$ electrode. Samples for trace element chemistry back at the shore-based laboratory were filtered (Nucleopore $0.1 \mu \mathrm{m}$ ) and acidified with ultrapure nitric acid. The filters were stored for microscopic examination. The temperature of the samples and the ambient seawater were determined in situ with the temperature probe $\left( \pm 0.005^{\circ} \mathrm{C}\right)$ attached to one of the arms of "Nautile". During shipboard subsampling and handling the temperature was generally less than $7^{\circ} \mathrm{C}$. Gas overpressure was also found in several samples (HY3, 5, 7. 8, 11, 18). In the shore-based laboratory ${ }^{18} \mathrm{O} /{ }^{16} \mathrm{O}$ and $\mathrm{D} / \mathrm{H}$ were measured by mass spectrometry and light hydrocarbons by gas chromatography. Methods for other elements are given in Table 2 together with accuracies. The filters were examined by SEM coupled with TRACOR to identify minerals. Some particles were also examined by $\mathrm{X}$-ray microdiffraction.

Results are given in Tables 3,4 and 5. Total dissolved sulfides were always less than $10^{-7} \mathrm{M}$. The major cations $\left(\mathrm{Li}^{+}, \mathrm{Na}^{+}, \mathrm{K}^{+}, \mathrm{Rb}^{+}, \mathrm{Mg}^{2+}\right.$, $\left.\mathrm{Ca}^{2+}, \mathrm{Sr}^{2+}\right)$ and anions $\left(\mathrm{Cl}^{-}, \mathrm{F}^{-}\right)$of seawater

TABLE 2

Analytical methods

\begin{tabular}{|c|c|c|c|}
\hline Element & Method & Standard & Accuracy \\
\hline $\mathrm{Na}, \mathrm{K}, \mathrm{Ca}$ & FAA & seawater ${ }^{\text {" }}$ & $2-39$ \\
\hline $\mathrm{Mg}$ & FAA & seawater & $3 \%$ \\
\hline $\mathrm{Li}, \mathrm{Rb}, \mathrm{Sr}$ & FAA & seawater & $5 \%$ \\
\hline $\left.\begin{array}{l}\text { Fe, } \mathrm{Mn}, \mathrm{Cu}, \mathrm{Co} \\
\mathrm{Mo}, \mathrm{Ba}, \mathrm{Pb}, \mathrm{Cd}\end{array}\right\}$ & ZCFAA & seawater & $5 \%$ \\
\hline $\mathrm{Cl}$ & $\mathrm{Ag}^{+} \mathrm{T}$ & & $0.2 \%$ \\
\hline$F$ & $\mathrm{P}$ & seawater & 19 \\
\hline $\mathrm{NO}_{3}, \mathrm{SO}_{4}$ & IC & seawater & $2 \%$ \\
\hline $\mathrm{Si}$ & $\mathrm{MC}$ & seawater & $1-2 \%$ \\
\hline Alk & $\mathbf{H}^{+} \mathbf{T}$ & seawater & $0.2 \%$ \\
\hline
\end{tabular}

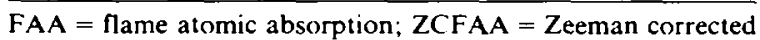
flameless atomic absorption; $\mathrm{Ag}^{+} \mathrm{T}=$ titration with $\mathrm{Hg}^{+}$using an $\mathrm{Ag}_{8}-\mathrm{A}_{2} \mathrm{~S}$ electrode; $\mathrm{P}=$ potentiometry with specific electrode: $\mathrm{IC}=$ ion chromatography; $\mathrm{MC}=$ molybdate colorimetry: $\mathrm{H}^{+} \mathrm{T}=$ acid titration.

"Seawater with addition of element. showed no significant variation. The only exception is a $1-2 \%$ decrease of $\mathrm{Mg}^{2+}$ in $\mathrm{HY} 4,7$ and 8 , accompanied by the decrease of the $\mathrm{Mg} / \mathrm{Cl}$ ratio. Considering that elements such as $\mathrm{Ca}, \mathrm{Mg}, \mathrm{Li}, \mathrm{Sr}$ show significant variations in the pore waters of nearby sediments $[4,5]$, this signifies that the fractions of advected pore fluid collected in these samples are less than $10 \%$. Hence the possibility of assessing the characteristics of such fluid will be limited. This point is discussed further below.

\section{Geochemical evidence for advection of pore waters}

We will first discuss the evidence for possible advection of fluids at the locations of sampling, then the characteristics of the fluids and possible controls on their compositions and last their origin and the rate and mode of advection of pore fluid.

The samples show no significant variations in the composition of the major dissolved cations and chloride which would have enabled us to place limits on the contribution of pore water to the total samples. However, in the absence of such clear diagnostic features several other important parameters and species show sufficient variations from which we can deduce the participation of pore fluids.

Of these the most straightforward evidence is the temperature anomalies measured in situ. We have found temperature anomalies in the range $0.1-0.45^{\circ} \mathrm{C}$ in the immediate vicinity of biological communities and anomalies in the range $0.01-0.03^{\circ} \mathrm{C}$ in the overlying bottom waters. Even if some may be due to biological activity, it is doubtful that significant temperature differences can be maintained in open waters if there is no input of fluids from the sediment. Similar temperature anomalies were also observed in the vicinity of fluid vents in the subduction zones off the coast of Oregon [1].

The small $\mathrm{Mg}^{2+}$ decrease in $\mathrm{HY} 4,7$ and 8 can also be related to mixing of advected pore fluids and to the temperature anomalies in the same site.

The occurrences of large concentrations of light hydrocarbons (about ten times the expected level for methane and much more for $\mathrm{C}_{2}$ and $\mathrm{C}_{3}$ ) are also related to advection of pore fluids (Table 5). The methane contents are in the same range as found in samples from the vent areas in the sub- 
TABLE 3

Water samples. Main parameters: temperature, $\mathrm{pH}$ and alkalinity (Alk) and composition of characteristic dissolved elements. The temperature readings are from the "Nautile" probe and the temperature differences $(\Delta T)$ were those observed during sampling with reference to ambiant deep ocean waters

\begin{tabular}{|c|c|c|c|c|c|c|c|c|c|}
\hline Sample & HY11 & HY12 & HY13 & HY2 & HYl & HY5 & HY4 & HY7 & HY8 \\
\hline Sampler & T.S. & B.C. & T.C. & T.S. & T.S. & T.S. & T.S. & T.S. & T.S. \\
\hline$T\left({ }^{\circ} \mathrm{C}\right)$ & & & & 1.03 & 1.04 & 1.20 & 1.20 & 1.41 & 1.60 \\
\hline$\Delta T\left({ }^{\circ} \mathrm{C}\right)$ & & & & 0 & 0 & 0 & & 0.21 & 0.40 \\
\hline $\mathrm{pH}$ & 8.28 & 8.0 & 7.83 & 8.21 & 8.06 & 7.90 & 8.05 & 8.14 & 8.02 \\
\hline Alk ${ }^{b}$ & 2.56 & 2.25 & 2.37 & 2.47 & 2.51 & 2.46 & 2.52 & 2.55 & 2.49 \\
\hline$\Sigma \mathrm{CO}_{2}{ }^{\mathrm{h}}$ & 2.26 & 2.16 & 2.32 & 2.23 & 2.42 & 2.34 & 2.32 & 2.30 & 2.33 \\
\hline $\mathrm{SiO}_{2} \mathrm{c}^{2}$ & 9.9 & 3.9 & 10. & .2 & 13.0 & 12.7 & 12.1 & 9.8 & 12.3 \\
\hline $\mathrm{SO}^{2-a}$ & 2.73 & 2.70 & 2.73 & 2.75 & 2.73 & 2.70 & 2.54 & 2.40 & 2.59 \\
\hline $\mathrm{NO}_{3}$ & 1.07 & & & 0.74 & 6.0 & 7.39 & 1.85 & 7.97 & 6.50 \\
\hline $\mathrm{Fc}^{\mathrm{d}}$ & 6.8 & 5.3 & 22.4 & 9.6 & 16.9 & 12.5 & 19.3 & 4.1 & 2.5 \\
\hline $\mathrm{Mn}^{\mathrm{d}}$ & 0.47 & 0.18 & 0.40 & 0.58 & 0.33 & 0.11 & 0.11 & 0.18 & 2.87 \\
\hline $\mathrm{Cu}^{d}$ & 0.75 & 0.66 & 0.85 & 1.35 & 1.45 & 1.89 & 2.80 & 0.85 & 1.19 \\
\hline $\mathrm{Mo}^{\mathrm{d}}$ & 0.79 & 1.01 & 1.08 & 0.72 & 0.86 & 0.23 & 1.01 & 1.73 & 0.77 \\
\hline $\mathrm{Ba}^{\mathrm{d}}$ & 1.42 & 0.98 & 1.8 & 0.52 & 1.31 & 0.51 & 0.80 & 0.46 & 0.35 \\
\hline Sample & HY9 & HY10 & HY6 & HY3 & HY18 & HY 19 & HYl4 & HY15 & HY16 \\
\hline Sampler & B.C. & T.C. & T.C. & T.C. & T.S. & T.C. & T.S. & T.S. & T.S. \\
\hline$T\left(^{\circ}\right)$ & 1.41 & 1.63 & 1.20 & 1.20 & 1.20 & 1.20 & & 1.13 & 1.11 \\
\hline$\Delta T\left({ }^{\circ} \mathrm{C}\right)$ & 0.21 & 0.43 & & & 0 & 0 & & 0.02 & 0 \\
\hline $\mathrm{pH}$ & 7.74 & 7.92 & 7.82 & 8.30 & 8.20 & 8.01 & 8.15 & 8.16 & 8.01 \\
\hline Alk ${ }^{b}$ & 2.43 & 2.34 & 2.39 & 2.54 & 2.56 & n.m. & 2.585 & 2.59 & 2.48 \\
\hline $2 \mathrm{CO}_{2}{ }^{\mathrm{b}}$ & 2.37 & 2.23 & 2.33 & 2.26 & 2.30 & & 2.45 & 2.40 & 2.33 \\
\hline $\mathrm{SiO}_{2}^{\mathrm{c}}$ & 7.7 & 11.2 & 14.7 & 7.1 & 10.2 & 9.8 & 11.9 & 12.6 & 12.7 \\
\hline $\mathrm{SO}_{4}^{2}$ & 2.19 & 2.68 & 2.46 & 2.52 & 2.72 & 2.74 & 2.60 & 2.63 & 2.70 \\
\hline $\mathrm{NO}_{3}^{-c}$ & & 0.097 & & 3.45 & 5.03 & & & & \\
\hline $\mathrm{Fe}^{\mathrm{d}}$ & 17.6 & 4.2 & 16.5 & 7.5 & 6.8 & 14.7 & $<0.2$ & 8.0 & 7.9 \\
\hline $\mathrm{Mn}^{\mathrm{d}}$ & 5.39 & 4.77 & 9.21 & & 0.14 & 2.18 & 0.40 & 0.11 & 0.14 \\
\hline $\mathrm{Cu}^{\mathrm{s}}$ & 5.10 & 0.92 & 1.01 & 4.56 & 2.96 & n.m. & 3.15 & 4.56 & 1.64 \\
\hline$M \sigma^{d}$ & 1.23 & 0.94 & 1.01 & & 0.94 & 0.86 & 0.45 & 0.58 & 1.23 \\
\hline $\mathrm{Ba}^{\mathrm{d}}$ & 1.12 & 1.79 & 0.79 & 0.86 & 0.76 & 0.75 & 1.17 & 1.39 & 1.82 \\
\hline
\end{tabular}

Concentration scales: ${ }^{a} 10^{-2} \mathrm{M} ;{ }^{b} 10 \cdot{ }^{3} \mathrm{M}:{ }^{c} 10{ }^{5} \mathrm{M} ;{ }^{d} 10{ }^{7} \mathrm{M}$.

$\mathrm{Pb}$ and $\mathrm{Cd}$ concentrations were always less than $10^{8} \mathrm{M}$. except HY9 with $3 \times 10^{-8} \mathrm{M}$. n.m. - not measured. For sampler, see Table 1 .

TABILF: 4

${ }^{18} \mathrm{O} /{ }^{16} \mathrm{O}$ and $\mathrm{D} / \mathrm{H}$ of water samples (expressed in $\delta c^{\circ}$. units versus SMOW standard)

\begin{tabular}{|c|c|c|c|c|c|c|c|c|c|c|c|c|}
\hline & HY 11 & HY2 & HY1 & HY5 & HY4 & HY7 & HY 8 & HY3 & HY18 & HY 14 & HY15 & HYl6 \\
\hline$\delta^{18} \mathrm{O}$ & -0.35 & -0.24 & -0.39 & -0.32 & -0.39 & 0.27 & -0.30 & -0.25 & -0.30 & -0.37 & -0.47 & 0.45 \\
\hline$\delta \mathrm{D}$ & -0.96 & -1.19 & -1.31 & -0.18 & +1.94 & .0 .57 & -0.08 & -0.97 & 3.91 & -6.21 & 6.39 & 6.29 \\
\hline
\end{tabular}

TABLE 5

Methane $\left(C_{3}\right)$. ethane $\left(C_{2}\right)$ and propane $\left(C_{3}\right)$ concentrations in water samples expressed in $\mathrm{nl} / \mathrm{l}$

\begin{tabular}{lrrrrrc}
\hline Sample & HY4 & HY7 & HY3 & HY14 & HY15 & HY16 \\
\hline$C_{1}$ & 111 & 72 & 72 & 60 & 112 & 82 \\
$C_{2}$ & 20 & $<1$ & 5 & 12 & 18 & 13 \\
$C_{3}$ & 3 & $<1$ & $<1$ & $<1$ & $<1$ & $<1$ \\
$C_{1} /\left(C_{2}+C_{3}\right)$ & 5 & & 13 & 5 & 6 & 6 \\
\hline
\end{tabular}

duction area off Oregon [1]. The $C_{1} /\left(C_{2}+C_{3}\right)$ ratios are very low. which may be indicative of: (1) extreme oxidation of a microbiologically produced hydrocarbon pool, mostly of methane, in the upper $50 \mathrm{~m}$ of the sedimens $[6,7]$; or (2) input from thermogenic hydrocarbons. In this case they should have been produced at temperatures higher than $60^{\circ} \mathrm{C}$. Thermogenic hydrocarbons may also 
have been partially oxidized in the upper part of the sediment. A mixture of both sources of hydrocarbons is also possible.

The decrease in concentrations of sulfate found in several samples collected above the seafloor (HY4, 6. 7, 8, 9, 3, 14, 15) is also characteristic of the advection of pore fluids. It is difficult to ascribe the decrease in sulfate contents to the sulfate-reducing bacteria, since the variations are not accompanied by an increase in dissolved nutrients and total dissolved carbonates. In the area off Japan such an expected correlation between $\mathrm{SO}_{4}$, nutrients and dissolved carbonates is found in sediments from the Nankai area collected during the DSDP program [5]. The decrease in sulfate contents can be due to a contribution of advected pore water in the vicinity of biological communities since similar sediments collected in the Tenryu Canyon (HY12, 13) do not present this decrease of sulfate content. The decrease in sulfate in the open waters show that the percentage of advected pore fluid that was collected is at least $5 \%$ for HY8, 14 and $15,8 \%$ for HY 3 and 4 and more than $10 \%$ for HY7.

Thus temperature anomalies and several anomalies of dissolved constituents point out that the water samples collected above biological communities (HY4, 7, 8, 14, 15) or above geological structure (HY3) may represent a mixture of normal oceanic seawater and advected pore waters.

In the Nankai Trough area the results obtained during the DSDP program [5,7] have shown that diagenesis has induced only limited changes in the pore waters in the upper hundred meters of the sediment column. The mixing of such pore water with deep-sea water should therefore not be expected to yield large deviations in concentrations of the major elements. Also, the metabolism of the Calyptogena may have induced changes in the advected pore waters such as oxidation of light hydrocarbons and uptake of carbon dioxide, hydrogen sulfide [8], and of metals such as Fe, Mn, $\mathrm{Cd}, \mathrm{Mo}$ [9]. Hence it is difficult to assess the exact end-member composition of the advecting fluid.

\section{Geochemical characteristics of the fluids col- lected during Kaiko}

Apart from the characteristics discussed above the chemistry of the samples is generally not very different from that of seawater collected at the sediment interface.

The alkalinity (Alk) versus total dissolved carbonate $\left(\Sigma\left[\mathrm{CO}_{2}\right]\right)$ diagram, (Fig. 3) shows that most of the free bottom water samples are in the range expected for deep Pacific Ocean water [10]. The expected variation $\left(\Delta \mathrm{Alk} / \Delta \Sigma\left[\mathrm{CO}_{2}\right]\right.$ ) for Pacific deep waters was found for HY5 and HY1 in the Tenryu Canyon deep-sea fan. The supernatant waters (HY6, 9, 10, 12, 13) also show a similar relation characteristic of carbonate dissolution and degradation of organic matter [10]. It is possible that mostly carbonate dissolution is important in samples HY2, 3, 11, 18 [10]. The Alk$\Sigma\left[\mathrm{CO}_{2}\right]$ values for the samples where advection of pore water and changes due to clam metabolism are expected do not generally follow the above trends. From the Alk- $\Sigma\left[\mathrm{CO}_{2}\right]$ relation and Alk-pH relation it can be deduced that samples $\mathrm{HY} 4,7,8$, $14,15.16$, associated with biological communities have higher alkalinity and lower $\Sigma\left[\mathrm{CO}_{2}\right]$ than expected. These may be due to advected pore water input and dissolved carbonate uptake by the

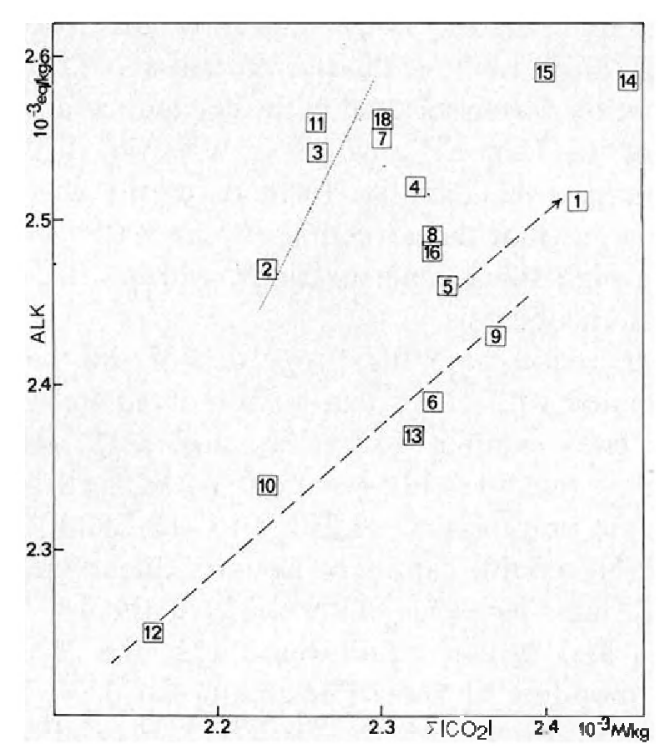

Fig. 3. Alkalinity (Alk) vs. total dissolved carbonate $\left(2\left[\mathrm{CO}_{2}\right]\right)$ diagram. The numbers correspond to the sample references. The square surrounding the sample number corresponds approximatively to the analytical uncertainty. The dashed lines correspond to the relation $\left(\Delta \mathrm{Alk} / \Delta \mathrm{\Sigma}\left[\mathrm{CO}_{2}\right]\right)=0.93$ expected for deep Pacific waters (see [10]). The lower line corresponds to the supernatant water samples. The dotted line corresponds to the relation during carbonate dissolution. 
clams. Samples HY15 and HY16 were collected exactly at the same site, with a large dilution by seawater for HY16 (as shown by the values of $\Delta T$, $\mathrm{SO}_{4}$ and $\mathrm{CH}_{4}$ ). The Alk and $2\left[\mathrm{CO}_{2}\right]$ values imply that the advected pore water has in this case higher alkalinity and total dissolved carbonate. This is in agreement with pore waters characteristics found during the DSDP [4,5]. Thus the alkalinity-total dissolved carbonate relations show that the advected pore water has indeed higher concentrations than local seawater. However, the uptake of carbonate and ions (such as $\mathrm{Ca}^{2+}$ ) for metabolism purpose by the clams [8.9] makes it difficult to deduce more accurately the properties of the advected pore water.

The nitrate and silica concentrations are variable and some are not in the ranges expected for deep-sea water [10]. Samples HY2 and 11 where the degradation of organic matter was limited on the basis of the Alk- $\Sigma\left[\mathrm{CO}_{2}\right]$ relation have low nitrate and low silica concentrations; samples HY 1 and 5, where this relation is more extensive, have higher nitrate and silica concentration, as expected. The samples associated with the biological communities have very variable nitrate concentrations and higher silica concentrations (except HY7). Since we have discovered that some silicate formation was associated with the clam communities of the Tenryu Canyon it is, however, difficult to interpret this data (see further section). One can only argue that the advection of pore water should bring high silica concentrations, which will favor silicate neogenesis.

The redox potential properties of the waters associated with clams can be computed from the two redox couples $\mathrm{CO}_{2} / \mathrm{CH}_{4}$ and $\mathrm{SO}_{4}^{2-} / \mathrm{HS}$. The first one gives $\mathrm{Eh}=-0.260 \mathrm{~V}$ and the second is in the range $\mathrm{Eh}=-0.250 \mathrm{~V}$ to $-0.280 \mathrm{~V}$. The $\mathrm{N}_{2} / \mathrm{NH}_{4}$ couple cannot be assessed due to lack of $\mathrm{NH}_{4}^{+}$data. However, with $\mathrm{NH}_{4}^{+}$in the $10^{5} \mathrm{M}$ range and $N_{2}$ in equilibrium with the air the corresponding Eh should be about $-0.260 \mathrm{~V}$. This is an indication that the $\mathrm{N}_{2} / \mathrm{NH}_{4}^{-}$may also be active in the vicinity of the clams, which would be in agreement with $\mathrm{N}_{2}$ uptake by the clams [8].

The trace element geochemistry is difficult to decipher. Several causes may affect their concentrations and they are very sensitive to the biological activity [8,9]. Also pollution due to the sampling tools and to the submersible is affecting numerous metals. We have only given the results for the trace metals for which this last factor is negligible. As expected near the sediment-water interface. the concentrations of iron, copper and manganese are much higher than in open ocean water. There is, however, no clear trend appearing for these metals. In the samples where sulfate depletion was observed and where hydrogen sulfide was produced, the iron concentrations are in the range expected for equilibrium with greigite $\left(\mathrm{Fe}_{3} \mathrm{~S}_{4}\right)$ or pyrite $\left(\mathrm{FeS}_{2}\right)$ [11]. In the same samples the concentrations of copper should be controlled by sulfide formation as well. This is in agreement with the finding of metal sulfides on the corresponding filters (see further section below).

The concentrations of molybdenum are in the range expected for ocean water near the sea bottom-water interface [12]. At the measured concentrations of hydrogen sulfide $\left(\leqslant 10^{7} \mathrm{M}\right)$ and Eh conditions discussed above, the range of molybdenum concentrations correspond to equilibrium between $\mathrm{MoO}_{4}^{2-}$ and $\mathrm{MoS}_{2}$.

Barium concentrations are in the range found in deep-ocean waters from near the sediment interface [13]. The ion activity product (I.A.P.) of barium sulfate of the water samples, calculated with correction as given by Church [13], is quite variable: from $1.8 \times 10^{-11}$ to $10.5 \times 10^{-11}$. Since the sulfate concentration is almost constant in the samples where no activity from vent organisms was noticed, the variations in I.A.P. correspond to local variations of the barium concentration. Thus we find that the barium concentrations in the free bottom waters are decreasing from the northern Kurile waters towards the south. These points are illustrated in Fig. 4, in a plot of I.A.P. versus Ba. The afore-mentioned "non-biological" samples are linearly correlated in the I.A.P.-Ba plot (Fig. 4). The samples where sulfate depletion was noticed are well off this correlation. This can be due to several causes discussed in the following. Their positions suggest that deposition of $\mathrm{BaSO}_{4}$ may have occurred in several cases. A simple mixing model between local seawater and an unknown advected pore water can be computed for both $\mathrm{Ba}$ and $\mathrm{SO}_{4}$. The computations can be done by considering the constraints imposed on the mixing ratio of an advected pore water with local deep free water due to the decrease of sulfate, which lead to limiting conditions for $\mathrm{Ba}, \mathrm{SO}_{4}$, and I.A.P. 


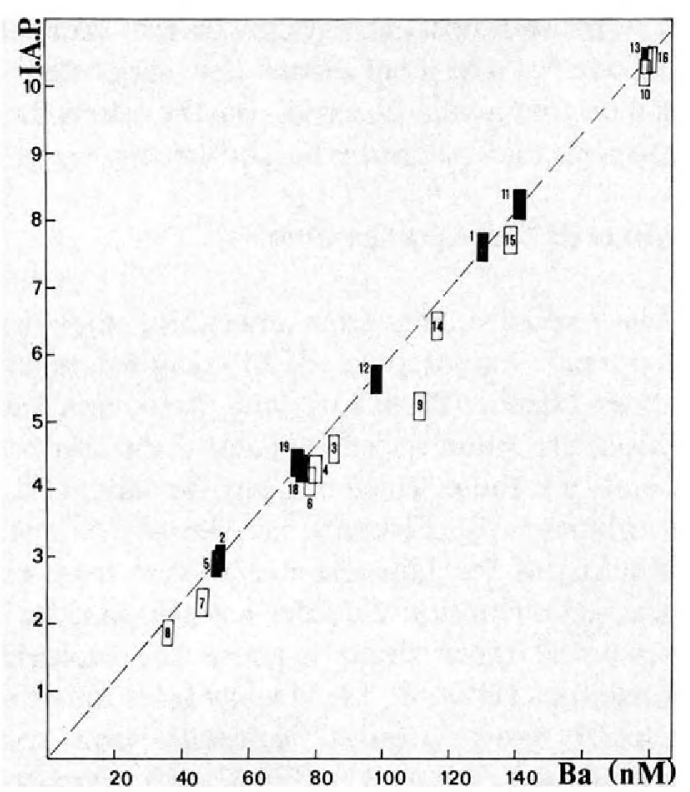

Fig. 4. Ion activity product (1.A.P.) for $\mathrm{BaSO}_{4}$ versus barium concentration in Kaiko samples. The I.A.P. scale is multiplied by $10^{11}$. The dashed line corresponds to the relation betwcen the "non-biological" samples (HY1, 2, 5, 11, 12, 13, 18, 19). The rectangle with the sample number corresponds to the uncertainty. The black rectangles are those of the open occan bottom water samples.

for the advected pore water end-member. The results of these calculations are given in Fig. 5. For samples HY3, 4, 6, 9 from the Tenryu Canyon, HY14 from the Kashima Seamount and HY15 from the Kurile Trench the pore water end-member have $\mathrm{SO}_{4}$ in the range $0.3-0.6 \times 10^{-2} \mathrm{M}, \mathrm{Ba}$ in the range $300-700 \mathrm{nM}$ in the Tenryu and $700-1000 \mathrm{nM}$ in the Kashima and Kurile areas. The low sulfate values are in agreement with pore water compositions found in the DSDP samples from the same areas [4,5]. If we consider this end-member it implies that the passage of the advected waters through the clam colonies in the Tenryu Canyon have led to $\mathrm{BaSO}_{4}$ deposition (seen from samples HY7, 8). This is shown by the lower Ba contents in $\mathrm{HY} 7$ and $\mathrm{HY} 8$ as compared to local deep waters (HY2 and HY5) and the computed composition of the deep component (Fig. 5). In sample $\mathrm{HY} 10$ redissolution of $\mathrm{BaSO}_{4}$ may have taken place next to the clam colonies. In the case of the Kurile Trench there are two possibilities: (1) redissolution of barium sulfate in the vicinity of the colonies (seen from HY16) or (2)

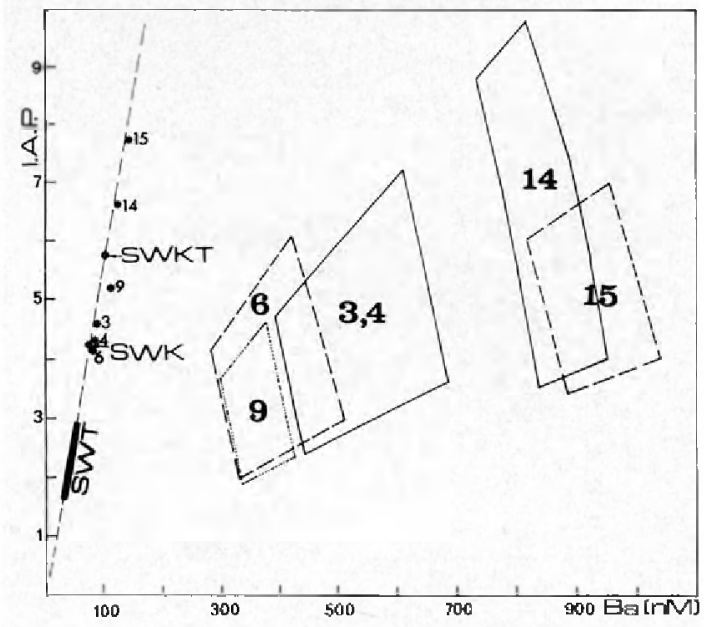

Fig. 5. Ion actuvity product (I.A.P.) for $\mathrm{BaSO}_{4}$ versus barium concentration for possible advected pore water end-member. The numbered stars are the Kaiko samples. SWT is the condition corresponding to the Tenryu Canyon area. SWK is that corresponding to the Kashima Seamount area, and SWKT is that corresponding to the Kurile Trench. The numbered areas correspond to the computed I.A.P. and $\mathrm{Ba}$ conditions for the pore water end-members. The dashed line corresponds to the I.A.P.-Ba relation for the "non-biological" Kaiko samples (see Fig. 4).

deposition of $\mathrm{BaSO}_{4}$ linked to clam metabolism (seen in this case from HY15). Thus one should expect a barium anomaly in connection with the biological communities. This is what we have found upon examination of the biological samples and the sediments [9].

A last discussed feature of the deep-water samples is their oxygen isotope and $\mathrm{D} / \mathrm{H}$ characteristics (Fig. 6). We will only discuss the Nankai area where several samples are available. The $\delta^{18} \mathrm{O}$ are in the range expected for the Pacific deep bottom waters. If mixing had occurred with waters derived from the upper part of the sedimentary column one should expect a slight shift towards more heavy oxygen isotope values as found during DSDP Leg 87 [14]. In the Nankai Trough area, where eight samples were obtained, the shift is rather towards more light oxygen values which may reflect mixing with waters originated from deeper in the sediment column as expected from the light hydrocarbons data. A puzzling effect is an enrichment in deuterium correlated with the decrease of $\delta^{18} \mathrm{O}$ (called "Nankai area mixing line" in Fig. 6). Since this shift is larger in samples 


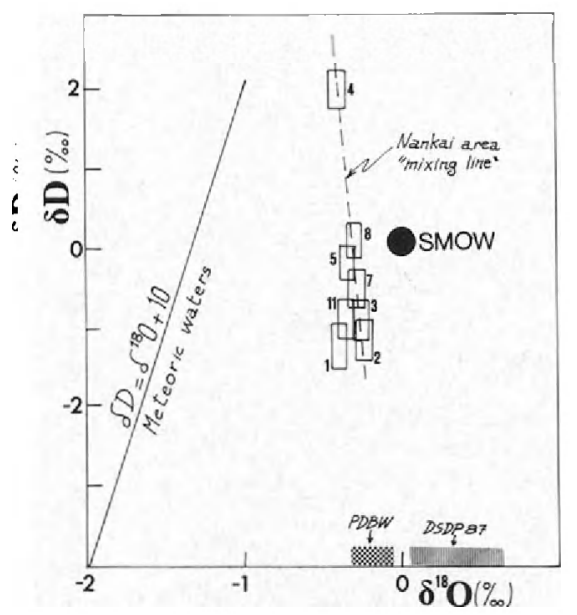

Fig. 6. $\delta \mathrm{D}-\delta^{18} \mathrm{O}$ relationship in fluid samples (titanium syringe). Data in permil versus SMOW. The meteoric water line is given as well as the "mixing line" for the Nankai Trough samples The area of the rectangle for each sample corresponds to the measurement uncertainties. The sample number is given near the rectangle. On the $\delta^{18} \mathrm{O}$ scale "P.D.B.W" corresponds to the range for Pacific decp bottom waters and "DSDP87" to the range found in the upper sediments from the Nankai Trough investigated during DSDP Leg 87 [14].

where methane was in larger concentration (HY4) this may be characteristic of the pore fluid. It may also be a sampling artefact, however, not explainable.

Thus, the geochemistry of the water samples also illustrates the input of advected pore waters and of the biological activity of the vent community. Some of the conclusions are supported by authigenic minerals observed on the filters from the syringes and the supernatant waters.

\section{Minerals found on the filters}

The overall results from examining the filters by optical microscopy, SEM coupled energy analyser (JEOL/TRACOR) and X-ray microdiffraction. are summarized in Table 6. Most of the minerals are those which can also be identified in the sediments [9], and they are derived from the weathering of the Japanese islands and from biological sedimentation. Sulfides are associated with the samples taken directly above the biological communities (HY4. 8, 15). The sulfides identified are mostly pyrite, iron sulfides with some small percentage of $\mathrm{Zn}$ and $\mathrm{Cu}$ (Fig. 7a. b), pyrrhotite (Fig. 7c); a single crystal of $\mathrm{MoS}_{2}$ has also been identified. These findings are in agreement with the water chemistry. In places some oxide overgrowths are found (Fig. 7d)). Calcium carbonates with very different morphologies were also identified. Several correspond to spicules from compound ascidians [15]. Ascidians were indeed identified on the shells of clams [8] and upon examination of photographs taken from the "Nautile" [16]. Calcium carbonates framboids were also found (Fig. 7e). they are almost pure calcium carbonate and a thin organic matter veil is left

TABLE 6

Minerals observed by microscopic examination of the filters

\begin{tabular}{|c|c|c|c|c|c|c|c|c|c|}
\hline Sample & HY11 & HY4 & HY7 & HY8 & HY9 & HY10 & HY18 & HY15 & HY16 \\
\hline Prismatic rutile & $?$ & + & + & + & + & + & + & - & - \\
\hline Black opaques (oxides) & - & + & - & + & - & - & - & - & - \\
\hline Sulfides & - & +++ & - & + & - & - & - & + & - \\
\hline White mica & - & -- & + & $-\quad$. & - & + & + & - & - \\
\hline Green or black mica & - & + & + & + & - & + & + & - & - \\
\hline Green silicates & + & + & - & - & - & - & - & + & - \\
\hline Quartz fragments & + & + & + & + & + & + & + & + & + \\
\hline Diatom (complete or fragments) & + & + & + & + & + & - & + & + & + \\
\hline Graphite and graphitoids & - & + & + & + & + & + & - & $?$ & $?$ \\
\hline Iron oxyhydroxides & - & + & + & + & - & + & + & + & - \\
\hline White clay mineral & - & - & ++ & ++ & ++ & ++ & - & - & - \\
\hline $\begin{array}{l}\text { Metal fragments } \\
\text { (from submarine } \\
\text { or sampling devices) }\end{array}$ & + & + & - & - & - & - & - & + & + \\
\hline
\end{tabular}

$-=$ absent $+=$ frequent $++=$ abundant $+++=$ very abundant. 

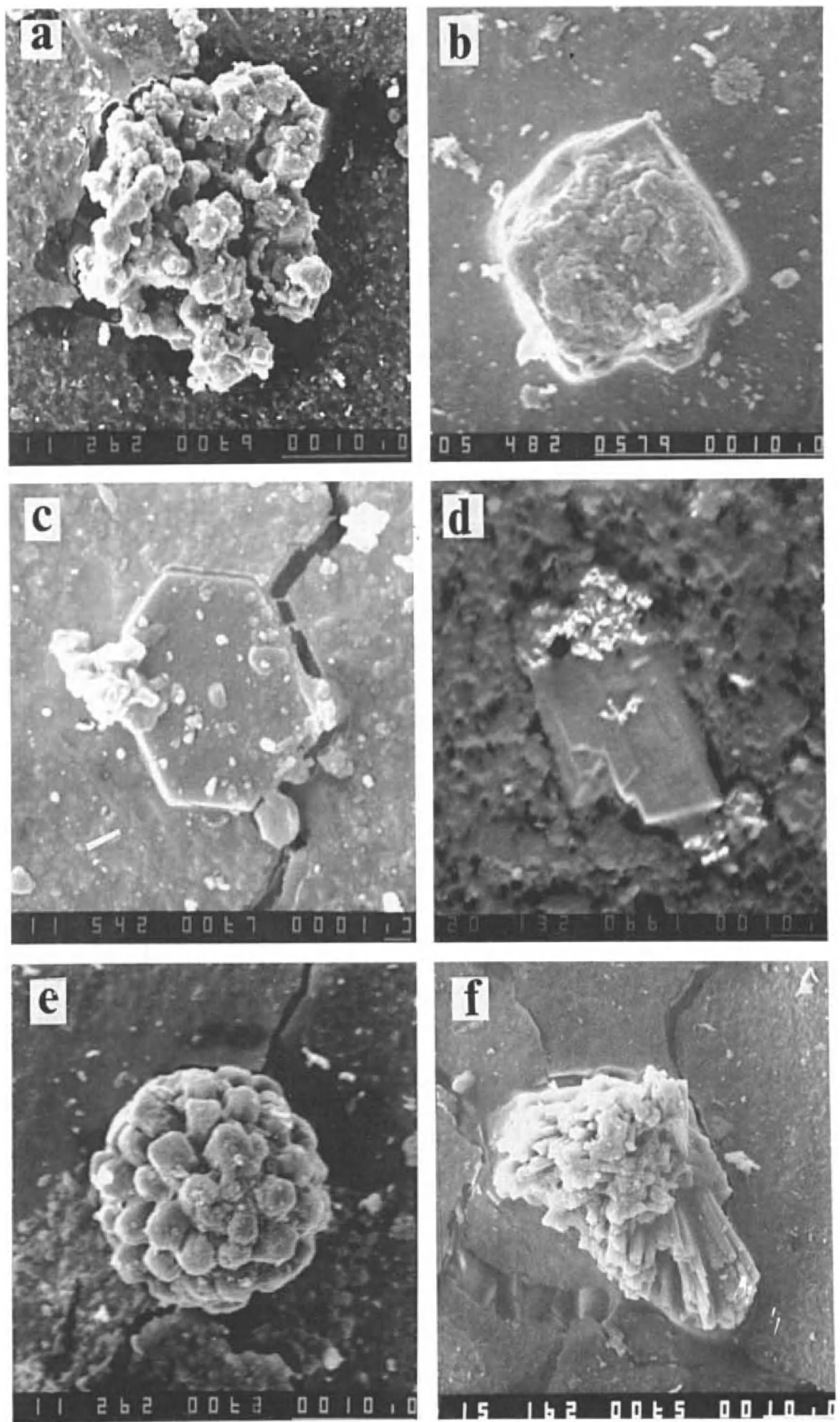

Fig. 7. SEM photographs of particles found on the filter corresponding to HY4. The scale bar is given in $\mu \mathrm{m}$ in the lower right angle of each view. (a) Cluster of small pyrite crystals. (b) Cube of pyrite covered by a $\mathrm{Zn}$-Fc sulfide. (c) Pyrrhotite crystal. (d) Small magnetite crystal (without $\mathrm{Ti}$ ) overgrowths partially covering a $\mathrm{Ca}-\mathrm{Fe}-\mathrm{Mg}$ alumino-silicate crystal. (e) Calcium carbonate (without $\mathrm{Mg}, \mathrm{Mn}$. Fe) framboid. (f) Calcium carbonate crystals stacked together (traces of $\mathrm{Fe}, \mathrm{Mg}$ and $\mathrm{Mn}$ ). 
upon acid dissolution. They are probably of biological origin, however, not identified. Stacks of calcium carbonate crystals, containing traces of Fe. Mg. Mn were also found (Fig. 7f). They are probably of inorganic origin. X-ray microdiffraction revealed that vaterite, calcium carbonate monohydrate as well as aragonite and calcite are present. Calcium carbonate hydrate suggests that it may be derived from methanehydrate yielding $\mathrm{CaCO}_{3}, 6 \mathrm{H}_{2} \mathrm{O}$ (ikaite) which then decomposes at lower pressure [17]. Such unstable calcium carbonates have been identified in the deformed sediments from the Nankai Trough during DSDP Leg 87 [18] and in the vents off Oregon coast [1] and are the precursors of pseudomorphes in ancient subduction zones of Japan and Oregon. Thus the presence of calcium carbonate hydrates seems to be related to the advection of methane.

In the Tenryu Canyon biological vent community a white clay mineral with a fluffy appearance was also abundant. Although difficult to isolate, $\mathrm{X}$-ray diffraction suggests that it maybe a smectite. This implies the presence of silica in much larger concentration than in seawater and hence its formation may be related to advection of pore water.

\section{Discussion}

Although the samples we have collected during the Kaiko legs result from a complex mixing between ambient open ocean deep-sea water and pore water from the sediment, there are good geochemical data which show that part of these fluids have components which may have a deep origin. The association of the biological communities with these geochemical anomalies and with deep geological structures (from seismic data) also suggest a local input of chemicals and nutrients by fluid venting. Here we wish to discuss further the possibility of a deep component input to surface sediments and to assess the characteristics of pore fluid migration with special emphasis on the Nankai Trough area where data from DSDP are available.

The methane concentrations, and the $\mathrm{C}_{1} /\left(\mathrm{C}_{2}+\right.$ $\left.\mathrm{C}_{3}\right)$ ratios, of the samples raise several questions: (1) what is the origin of the hydrocarbons?; (2) what is the background concentration of methane in deep-sea water from subduction areas? This last question is difficult to answer straightforwardly since what we thought was a background sample (HY3) may be associated with a structure favorable to fluid venting according to the bottom photographs and its sulfate depletion. Methane concentration in the same range as $\mathrm{HY} 3(50-70 \mathrm{nl} / \mathrm{l})$ were found in water samples taken several miles from the subduction of the Oregon margin [1]. It is possible that background concentration in subduction area are several times larger than the expected $10 \mathrm{nl} / \mathrm{l}$. In $\mathrm{HY} 3$ the $\mathrm{C}_{1} /\left(\mathrm{C}_{2}+\mathrm{C}_{3}\right)$ ratio is very low and suggests that the hydrocarbon concentrations are influenced by thermogenic methane input [19]. The concentration of light hydrocarbons introduced by advection of pore fluid may, however, have been reduced by oxidation in the upper part of the sediment column $[8,20]$. With the help of the constraint due to sulfate depletions, the methane concentration that can be deduced for the advected component in HY 3 is about $600 \mathrm{nl} / 1$, reflecting the low concentration due to oxidation. In the pore waters of sediments where advection of thermogenic hydrocarbons was found, however, not from the Oregon margin, concentrations in the range $10-100 \times 10^{3}$ $\mathrm{nl} / \mathrm{l}$ were obtained [10]. In the deep-water samples clearly associated with biological activity (HY4, 7. $14,15,16)$ the methane concentrations are in the range of HY3 or larger. One should expect this since dilution of advected fluid and increase of consumption of light hydrocarbons have influenced this factor. The $\mathrm{C}_{1} /\left(\mathrm{C}_{2}+\mathrm{C}_{3}\right)$ ratio is even lower than in $\mathrm{HY} 3$, showing clearly the input of a thermogenic component. If $\mathrm{HY} 3$ represents a background sample for the hydrocarbons we can solve a simple mixing model with an advected end-member for $C_{1}, C_{2}$ and $C_{3}$. In the case of HY4, 15, 16, the corresponding advected endmember should be $C_{1}=400 \mathrm{nl} / 1$ and $C_{1} /\left(C_{2}+\right.$ $\mathrm{C}_{3}$ ) $=2$. These low concentrations are due to the oxidation of the light hydrocarbons. If we take the pore water value of $C_{1}=10-100 \times 10^{3} \mathrm{nl} / \mathrm{l}$, the amount oxidized is larger than $95-99.5 \%$ of the hydrocarbons.

Part of the methane encountered in the Kaiko sample can be derived from biogenic activity. However, in this case it is difficult to explain the $C_{2}$ and $C_{3}$ concentrations. The presence of thermogenic hydrocarbons in the samples should rather be used as an argument related to the 
plumbing of the advection of pore water. Since the clam colonies are located above thrusting structure, the thermogenic hydrocarbons are evidence for the deep penetration of these structures.

The light hydrocarbons are most probably of thermogenic origin. The biochemical studies have shown that the isotopic composition of the methane should be $\delta^{13} \mathrm{C}=-50$ to $-30 \%$ which is also characteristic of thermogenic methane [8]. Thermogenic hydrocarbons are produced at temperatures higher than $50-60^{\circ} \mathrm{C}$. The thermal gradient found in the Japan Trench is in the range of $15-36^{\circ} \mathrm{C} / \mathrm{km}[21,22]$. This yields depths in the range $1.5-3 \mathrm{~km}$ for the generation of the light hydrocarbons. This depth range compares favorably with that deduced from the methane/ethane ratio versus depth diagram obtained during DSDP Hole 440. According to that, the location of the source of thermogenic hydrocarbons should be around $2.5 \mathrm{~km} \mathrm{[3].} \mathrm{It} \mathrm{is} \mathrm{also} \mathrm{in} \mathrm{the} \mathrm{same} \mathrm{depth}$ range as the vertical projection of the thrust faults found in the Nankai accretionary prism [23], and for dewatering in accretionary prism [24].

The processes of migration of water through the prism during dewatering are not well known. The location of vents in close association with structure related to thrust faults as at the base of the Tenryu Canyon deep-sea fan suggests it occurs as shear dewatering, i.e. due to fracture permeability. The location of vents where erosional features allow the thrust faults to reach the sediment-water interface also suggests that the advection can be easily stopped or diverted if buried under sediment slump.

A simple modelization of the rate of advection of the fluid using a two-dimension steady-state model has been attempted [25]. It was found that it is not possible to sustain steady-state advection and that the rate of advection should be at least $5000 \mathrm{~cm} / \mathrm{yr}$ [25]. In this case the temperature anomalies observed can be obtained if cooling of the expelled fluid is effected by a lateral flux of seawater through the sediment near the vent location $[9,25]$. The geochemical anomalies, such as sulfate depletions, are also difficult to explain if we have low advection rates. The flux in the subduction areas off Japan is probably non-stable. This is in contrast with the stable steady-state fluxes computed from the geochemical anomalies obtained off the coast of Oregon [26] and the corresponding low rates of the pore fluid (1-10 $\mathrm{cm} / \mathrm{yr}$ ) for the case of Oregon [26]. Similar low rates have also been obtained to explain the thermal behavior of the subduction in the northern Japan Trench [27].

The case of fluid venting in the Tenryu Canyon area is well documented and geological as well geochemical characteristics can be compared with similar occurrences in the Oregon margin. The finding of fluid venting and biological communities associated with a thrust in the Kashima area (HY14) and in the Japan Trench [29] can be similarly understood. The possible occurrence of fluid venting in the Zenisu Basin (HY3) and the Kurile Trench scarp (HY15, 16) is more difficult to understand. In the case of the Zenisu Basin advection of fluid is suggested by the sulfate depletion and the low $\mathrm{C}_{1} /\left(\mathrm{C}_{2}+\mathrm{C}_{3}\right)$ ratio. The Seabeam data, the seismic data and the possibility of a thrust structure in the Zenisu Basin [28], correspond to compressive stresses which are favorable for fluid expulsion. A small clam colony at the apex of a fold above a thrust fault at the southernmost deformation front of the Zenisu area [28] may be related to this interpretation. In the Kurile area, the temperature and geochemical anomalies as well as the presence of clam colonies make a clear cut case for active venting. The geological setting, however, of the structure which would allow such venting is less clear. We can note that the deep biological communities were aligned along $\mathrm{N} 330^{\circ}$ which is along the major structural direction of the southwest inner wall of the Kurile Trench. The characteristics of the fluid venting suggest that this structure must have penetrated deeply.

\section{Conclusions}

The deep waters sampled above biological communities in the Nankai Trough and the Japan Trench areas can be related to fluid venting in connection with the geological setting which would favor advection of the fluids yielded by dewatering. In the upward path these fluids are enriched with molecules and elements of deep sedimentary origin: light hydrocarbons, trace metals. Hydrogen sulfide is also probably brought in the upper part of the sediment as shown by the dissolved sulfate depletion and the presence of metal sulfides in the 
samples. Hydrogen sulfide is utilized by bacteria associated with the gills of the clams from the biological communities [8]. Geochemical and biogeochemical data also show that part of the methane is also utilized for nutrient requirements. The fluid sample compositions result from the mixture of these different processes and sources. The light hydrocarbon data suggest the depth scale of the fluid circulation: $1.5-3 \mathrm{~km}$ for the Nankai area. A model of fluid circulation suggests a non-steady-state advection rate of at least 5000 $\mathrm{cm} / \mathrm{yr}$. The relation of the fluid vents to overpressure along the thrusting plane in the Nankai Trough and the deep origin of some of the fluid components give a good base for the use of the electro kinetic properties of the venting fluids for prevision of earthquake in this area [30].

The results obtained in this geochemical study have also important implications concerning the budget of elements in the ocean. For instance, the budget of methane and light hydrocarbons will probably have to be reassessed. Thus the quantitative importance of the preliminary results presented here will only be possible when a more complete overview of the importance of fluid venting in subduction areas will be obtained.

\section{Acknowledgements}

We acknowledge the invaluable assistance of the "Nautile" group and the help of $\mathrm{R} / \mathrm{V}$ "Nadir". crew members. We thank the Kaiko Planning Committee for giving access to shipboard sampling and $\mathrm{H}$. Bougault. L. Floury. C. Levèque and M. Sibuet, all from IFREMER, for help with instrumentation. Part of the analytical study was done by Dr. A.M. de Kersabiec and F. Vidot. This study was partly supported by grants from PIROCEAN/CNRS and IFREMER. We thank Dr. E. Suess for very helpful discussion on fluids in subduction areas.

\section{References}

1 L.D. Kulm. E. Suess, J.C. Moore. B.T. Lewis, S.D. Ritger. D.C. Kadko, T.M. Thornburg, R.W. Embley. W.D. Rugh. G.J. Massoth. M.G. Langseth. G.R. Cochrane and R.L. Scamman. Oregon subduction zone: venting. fauna and carbonates, Science 231, 561-566, 1986.

2 F. Suess, B. Carson. S.D. Ritger. J.C. Moore, M.J. Jones. L.D. Kulm and G.R. Cochrane. Biological communities at vent sites along the subduction z.one off Oregon, Biol. Soc. Wash. Bull. 6. 475-484. 1986.

3 J.K. Whelan and S. Sato. $C_{1}-C_{5}$ hydrocarbons from core gas pockets. Deep Sea Drilling Project Legs 56 and 57 . Japan Trench transect. in: Initial Reports of the Deep Siea Drilling Project 57, pp. 1335-1347. U.S. Government Printing Office. Washington D.C.. 1980.

4 G.W. Moore and J.M. Gieskes. Interaction betwcen sedjment and interstitial water near Japan Trench, Leg 57. Deep Sea Drilling Project, in: Initial Reports of the Deep Sea Drilling Project 57, p. 1269-1275, U.S. Government Printing Office. Washington D.C.. 1980.

5 H. Kawahata. K. Fujioka and T. Ishikuza, Sediments and interstitial water at Site 582 and 584 , the Nankai Trough and Japan Trench landward slope, in: Initial Reports of the Decp Sea Drilling Project 87, pp. 865-875, U.S. Government Printing Office. Washington. D.C.. 1986.

$6 \mathrm{M}$. Schoell, Recent advances in petroleum isotope geochemistry. Org. Geochem. 6, 645-663. 1984.

7 G.E. Claypool. A.K. Vuletich and K.A. Kvenvolden. Isotopic composition of interstitial fluids in sediment of the Nankai Trough, Deep Sea Drilling Project Leg 87, in: Initial Reports of the Deep Sea Drilling Project 87. pp. 857-860. U.S. Government Printing Office. Washington I).C. 1986 .

8 J. Boulègue, E.L. Benedetti, D. Dron, A. Mariotti and R. Letolle. Geochemical and biogeochemical observations on the biological communities associated with fluid venting in the Nankai Trough and Japan Trench subduction zones, liarth Planet. Sci. Lett. 83. 343-355. 1983 (this issue).

9 D. Iron. J. Boulègue. A. Taira and C. Rangin. Geochemistry of the Tenryu Canyon deep-sea fan biological community (Kaiko), Earth Planet. Sci. Lett. 83, 356-362, 1983 (this issue).

10 W.S. Broecker and T.H. Peng, Tracers in the Sea. $690 \mathrm{pp}$. Eldigio Press. New York. N.Y.. 1980.

$11 \mathrm{~J}$. Boulègue. Trace metals (Fe, Cu. $\mathrm{Zn}$. Cd) in anoxic environments, in: Trace Metals in Sea Water, NATO Conf. Ser., Mar. Sci., pp. 563-577, Plenum Press. New York, V.Y. 1983

12 K.K. Bertine. The deposition of molybdenum in anoxic waters. Mar. Chem. 1. 43-53, 1973.

13 T.M. Church. Marine Barite. 100 pp, Ph.D. Thesis. University of California at San IDiego. 1970.

$14 \mathrm{Y}$. Matsuhisa and R. Matsumoto. Oxygen isotope ratios of interstitial waters from the Nankai Trough and the Japan Trench, I.eg 87, in: Initial Reports of the Deep Sea Drilling Project 57. pp. 853-856. U.S. Government Printing Office. Washington D.C.. 1986.

15 B. Kniprath and F. Lafargue. Spicule formation in the Didemnidae, in: The Mechanism of Biomineralization in Animals and Plants, M. Omori and N. Watabe. eds., Tokai Liniversity Press. Tokyo, 1980.

16 L. Laubier and S. Ohta. Deep biological communities in the subduction zone of Japan from bottom photographs taken during "Nautile" dives in the Kaiko project, Earth Planet. Sci. L.ett. 83, 329-342. 1987 (this issue).

17 E. Suess, W. Balzer, K.F. Hesse. P.J. Muller. C.A. Ungerer and $G$. Wefer. Calcium carbonate hexahydrate from organic rich sediments of the Antarctic shelf: precursors of glendonites. Science 216, 1128-1131. 1984. 
18 C.L. Stein and A.J. Smith, Authigenic carbonate nodules in the Nankai Trough, Site 583, in: Initial Reports of the Deep Sea Drilling Project 87, pp. 659-666, U.S. Government Printing Office, Washington D.C., 1986.

19 M.J. Whiticar, E. Suess and H. Wehner, Thermogenic hydrocarbons in surface sediments of the Bransfield strait, Antarctica Peninsula. Nature 314, 87-90, 1985.

20 R.Y. Stanier, M. Doudoroff and E.A. Adelberg, General Microbiology, Macillan, London, 1971.

21 Shipboard Scientific Party, Sites 438 and 439: Japan Deep Sea Terrace, Leg 57, in: Initial Reports of the Deep Sea Drilling Project 56/57 pp. 23-191. U.S. Government Printing Office, Washington D.C.. 1980.

22 Shipboard Scientific Party. Sites 440: Japan Trench midslope Terrace. Leg 57, in: Initial Reports of the Deep Sea Drilling Project 56/57, pp. 225-317. L.S. Government Printing Office. Washington D.C., 1980.

23 C.J. Bray and D.E. Karig, Porosity of sediments in accretionary prisms and some implications for dewatering processes. J. Geophys. Res. 90, 768-778, 1985.

24 T.H. Shipley and G.F. Moore, Sediment accretion, subduction and dewatering at the base of the trench slope off Costa Rica a seismic reflection view of the décollement. J. Geophys. Res. 91, 2019-2028. 1986.
$25 \mathrm{X}$. Le Pichon, S. Lallemant and S. Lallemand, Tectonic context of fluid venting along Japanese trenches, Abstr.. Int. Kaiko Conf. on Subduction Zones, November 10-15, Tokyo 1986, 2-1, p. 24.

26 M.W. Han and E. Suess, Chemical evidence of pore venting in the Oregon subduction zone, EOS 57, 1219, 1986.

27 B.H. Reck, Effect of water flow from dewatering subducted sediments on thermal gradients in the Northeast Japan accretionary prism, EOS 67, 379, 1986.

$28 \mathrm{X}$. Le Pichon, T. Iiyamama, J. Boulègue, J. Charvet. M. Faure, K. Kano, S. Lallemant, H. Okada, C. Rangin. A. Taira, T. Urabe and S. Uyeda, Nankai Trough and Zenisu Ridge: a deep-sea submersible survey, Earthy Planet. Sci. Lett. 83, 285-299, 1987 (this issue).

29 J.P. Cadet, K. Kobayashi, J. Aubouin, J. Boulègue, J. Dubois, H. Hotta, T. Ishii, L. Jolivet, K. Konishi, S. Lallemand, N. Niitsuma and H. Shimamura. Deep scientific dives in Japan and Kuril Trenches. Earth Planet. Sci. $83,313-328,1987$ (this issue).

$30 \mathrm{~J}$. Boulègue, $X$. Le Pichon and T. Iiyama, Prévision des tremblements de terre dans la région de Tokai (Japon), C.R. Acad. Sci. Paris, Ser. II 301 1217-1219, 1985. 